\title{
ANALISIS KETERKAITAN RETURN ON EQUITY DAN EARNING PER SHARE TERHADAP NILAI PERUSAHAAN PADA PT. ASTRA AGRO LESTARI TBK.
}

Submitted Date :

12 April 2019

Accepted Date :

23 April 2019
Siti Dwi Ayuningsih

Universitas Muhammadiyah Sukabumi

Sdwi.Ayun@gmail.com

Erry Sunarya

Universitas Muhammadiyah Sukabumi

Nor Norisanti

Universitas Muhammadiyah Sukabumi

Abstract: This study aims to determine the effect of Return on Equity and Earning Per Share on the value of the company at PT. Astra Agro Lestari Tbk. In this study using secondary data, namely quarterly financial statements of PT. Astra Agro Lestari Tbk. 2010 to 2017 obtained through the Indonesia Stock Exchange website, www.idx.co.id. The analytical method used is multiple linear regression and data analysis using IBM SPSS Statistics 24 software. Based on the results of the analysis it can be concluded that Return on Equity and Earning Per Share have a negative and significant effect on firm value with $R 2$ of 0.643 , which means that variable contributions- independent variable on company value as indicated by Price to Book Value (PBV) at PT. Astra Agro Lestari Tbk. is $64.3 \%$ and the remaining $35.7 \%$ can be explained by other variables outside of this study. And based on the value of $R$ with a value of 0.802 , it indicates that the multiple correlations of the independent variables namely Return on Equity and Earning Per Share with the dependent variable, that is, the firm value is very strong.

Keywords: company value (PBV), Earning Per Share, Return on Equity

Abstrak: Penelitian ini bertujuan untuk mengetahui pengaruh Return on Equity dan Earning Per Share terhadap nilai perusahaan pada PT. Astra Agro Lestari Tbk. Dalam penelitian ini menggunakan data sekunder yaitu laporan keuangan triwulan PT. Astra Agro Lestari Tbk. tahun 2010 sampai 2017 yang diperoleh melalui website Bursa Efek Indonesia yaitu www.idx.co.id. Metode analisis yang digunakan yaitu regresi linear berganda dan analisis data menggunakan perangkat lunak SPSS IBM Statistik 24. Berdasarkan hasil analisis dapat disimpulkan bahwa Return on Equity dan Earning Per Share berpengaruh negatif dan signifikan terhadap nilai perusahaan dengan $R^{2}$ sebesar 0,643 , yang berarti bahwa kontribusi variabel-variabel independen terhadap nilai perusahaan yang diindikasikan dengan Price to Book Value (PBV) pada PT. Astra Agro Lestari Tbk. adalah sebesar $64,3 \%$ dan sisanya sebesar $35,7 \%$ dapat dijelaskan oleh variabel-variabel lain diluar penelitian ini. Dan berdasarkan nilai $R$ dengan nilai 0,802 menunjukkan bahwa korelasi ganda variabel independen yaitu Return on Equity dan Earning Per Share dengan variabel dependen yaitu nilai perusahaan adalah sangat kuat.

Kata kunci: Earning Per Share, nilai perusahaan (PBV), Return on Equity 


\section{Pendahuluan}

Perusahaan yang ingin melakukan ekspansi pastilah membutuhkan sumber pendanaan dan bisa diperoleh melalui pasar modal. Perusahaan yang menjual sahamnya di pasar modal disebut dengan perusahaan go public artinya informasi perusahaan tersebut terbuka bagi publik. Keterbukaan informasi perusahaan terhadap publik ini akan menimbulkan penilaian dari publik secara terbuka. Hal ini lah yang menjadi tujuan utama manajemen keuangan yaitu harus mampu memberikan nilai yang maksimal saat perusahaan masuk ke pasar. Memaksimalkan nilai perusahaan menjadi hal yang penting karena sama halnya dengan memaksimalkan kemakmuran pemegang saham.

Nilai perusahaan diartikan sebagai persepsi investor akan tingkat keberhasilan kinerja perusahaan dan sering dikaitkan dengan harga pasar saham (Hery, 2017). Nilai perusahaan juga mencerminkan kinerja keuangan perusahaan yang sering menjadi dasar keputusan dalam berinvestasi bagi investor. Dalam penelitian ini penulis memilih menggunakan Price to Book Value (PBV) atau Market to Book Ratio karena menurut Azis et al. (2015) nilai perusahaan lazimnya dapat diindikasikan dengan Price to Book Value (PBV). Selain itu menurut Marlina (2013) bahwa salah satu pendekatan untuk menentukan penilaian saham suatu perusahaan adalah dengan menggunakan Price to Book Value, juga dengan menggunakan PBV dapat menunjukkan seberapa besar perusahaan mampu menciptakan nilai perusahaan.

Investor cenderung bereaksi terhadap kinerja keuangan perusahaan dalam menghasilkan laba atau informasi besarnya laba yang mampu dihasilkan perusahaan. Karena seorang investor pastilah memiliki keinginan untuk memperoleh pembagian laba dalam bentuk dividend dan atau capital gain saat harga saham meningkat (Suripto, 2015). Peningkatan laba bersih perusahaan dapat memberikan sinyal yang positif bagi investor sehingga memicu investor untuk lebih menghargai nilai buku perusahaan yang akhirnya akan berdampak pada peningkatan nilai perusahaan, dengan kata lain investor akan cenderung menghargai nilai buku perusahaan lebih tinggi untuk saham-saham yang memberikan pengembalian yang baik.

Variabel independen yang digunakan untuk mengukur laba yang dihasilkan perusahaan dalam penelitian ini yaitu Return on Equity dan Earning Per Share. Kedua variabel ini merupakan faktor yang dapat mempengaruhi nilai perusahaan. Return on Equity menunjukkan laba bersih yang dihasilkan atas modal perusahaan atau modal yang telah diinvestasikan oleh investor. ROE merupakan perhitungan yang digunakan untuk menunjukkan keberhasilan atau kegagalan manajemen perusahaan dalam menghasilkan laba bersih atas modal yang telah diinvestasikan oleh pemegang saham (Astuti, 2004). Rasio ini digunakan untuk mengetahui efektivitas dan efesiensi pengelolaan modal sendiri yang dilakukan pihak manajemen dalam menghasilkan laba setelah pajak (Sudana, 2015).

Sedangkan Earning Per Share menunjukkan laba bersih atas setiap per lembar saham yang dimiliki oleh setiap investor. EPS merupakan perhitungan yang menunjukkan keberhasilan manajemen perusahaan dalam menghasilkan laba bersih per lembar saham atau keuntungan bagi pemegang saham (Kasmir, 2013). "Makin tinggi laba bersih yang diperoleh, makin tinggi pula Earning Per Share (EPS)" (Marlina, 2013), maka dari itu Earning Per Share bisa menjadi informasi mendasar bagi para investor karena dapat menggambarkan prospek keuntungan yang akan diterima oleh investor dimasa mendatang.

Penelitian ini ingin mengkaji mengenai keterkaitan Return on Equtiy dan Earning Per Share terhadap nilai perusahaan, yang mana objek dalam penelitian ini yaitu PT. Astra Agro Lestari Tbk. karena tercatat memiliki posisi harga saham yang kuat di sektor perkebunan selama rentang tahun 2010 sampai 2017.

Penelitian Puspitasari (2015) menunjukkan DER, DR, ROE, LNEPS, AGR, SGR, LNCR, dan ATR bersama-sama berpengaruh signifikan terhadap nilai perusahaan. Penelitian Marangu and Jagongo (2014) menunjukkan hubungan signifikan antara price to book value dengan dividend payout ratio, return on total asset, return on equity, return per share, dan dividend per share di NSE, Kenya. Penelitian Marlina (2013) menunjukkan earning per share, return on equity, debt to equity ratio, dan size secara simultan berpengaruh signifikan terhadap price to book value. Marlina (2013) juga menyatakan bahwa dengan adanya peningkatan laba maka earning per share meningkat, dengan meningkatnya aset perusahaan dari hutang akan memacu kemampuan manajemen perusahaan dalam mendapatkan laba, dan dengan meningkatnya laba investor juga berharap return 
yang semakin besar hal ini diharapkan dapat meningkatkan price to book value. Penelitian Christiana dan Putri (2017) menunjukkan bahwa terhadap price to book value secara parsial return on equity signifikan, tapi debt to equity ratio dan earning per share tidak signifikan, namun secara bersama-sama memiliki hubungan yang signifikan terhadap price to book value. Penelitian Suparno dan Ramadini (2017) menunjukkan baik parsial maupun simultan intellectual capital dan earning per share berpengaruh terhadap nilai perusahaan LQ45. Suparno dan Ramadini (2017) juga menyatakan "perusahaan dapat dikatakan mampu memaksimalkan nilai jika laba per saham yang mereka peroleh terus meningkat".

Menurut Suripto (2015: 32) menyatakan bahwa "earning sering digunakan sebagai indikator dalam pasar modal. Seringkali investor bereaksi setelah ada pengumuman tentang besarnya earning". Maka melalui Return on Equity dan Earning Per Share dapat menetapkan nilai dari suatu saham (Chug dan Meador (dalam Gumanti, 2011)), nilai saham sendiri sering dikaitkan dengan nilai perusahaan. Begitupun menurut Sudana (2015), bahwa "Nilai pasar saham perusahaan mencerminkan nilai perusahaan". Jika ROE dan EPS menurun kemungkinan investor cenderung menghindari membeli sahamnya sebab khawatir jika tidak menerima pengembalian yang diharapkan seiring dengan itu terjadi penurunan nilai perusahaan. "Makin tinggi laba bersih, makin tinggi harga sahamnya di pasar bursa dan saham itu diminati oleh calon investor" (Utari et al., 2014). Penelitian (Rosyada, 2017) juga menunjukkan bahwa secara parsial DER berpengaruh negatif signifikan terhadap nilai perusahaan sedangkan ROE dan EPS berpengaruh positif signifikan terhadap nilai perusahaan, secara simultan juga berpengaruh signifikan.

Berdasarkan uraian diatas maka tujuan penelitian ini adalah untuk mengetahui besarnya keterkaitan Return on Equity dan Earning Per Share terhadap nilai perusahaan pada PT. Astra Agro Lestari Tbk. periode 2010 sampai 2017.

\section{Metode}

Metode yang dipakai dalam penelitian adalah metode deskriptif dan metode asosiatif, menggunakan teknik analisis data regresi linear berganda dengan perangkat lunak SPSS IBM statistik 24. Metode penelitian deskriptif digunakan untuk mengetahui nilai variabel mandiri tanpa membandingkan (Sugiyono, 2013). Sedangkan metode asosiatif digunakan untuk mengetahui hubungan dua variabel atau lebih (Eti Rochaety, 2009).

Populasi dalam penelitian ini adalah seluruh laporan keuangan yang diterbitkan oleh PT. Astra Agro Lestari Tbk. dan sampel dalam penelitian ini adalah laporan keuangan per triwulan PT. Astra Agro Lestari Tbk. tahun 2010 sampai 2017.

Teknik pengumpulan data yang dipakai adalah data sekunder dalam penelitian adalah data dokumentasi berupa laporan keuangan yang diterbitkan PT. Astra Agro Lestari Tbk. tahun 2010 sampai 2017 yang diperoleh dengan mengakses situs resmi www.idx.co.id. Selain itu data juga diperoleh dari studi kepustakaan dengan mengkaji buku-buku, jurnal, dan karya tulis lainnya.

Teknik analisis data yang digunakan dengan perangkat lunak SPSS IBM statistik 24 adalah uji regresi. Dan untuk mengetahui nilai variabel penelitian menggunakan rumus sebagai berikut:

1. Variabel dependen

Variabel dependen (terikat) yang digunakan dalam penelitian ini adalah nilai perusahaan yang diukur dengan Price to Book Value (PBV). Menurut Sudana (2015) rumus untuk mencari nilai perusahaan yang diindikasikan dengan Price to Book Value adalah:

$$
\text { Market to Book Ratio }=\frac{\text { Market } \text { Price per Share }}{\text { Book Value per Share }}
$$


2. Variabel independen

Variabel independen (bebas) yang digunakan dalam penelitian ini adalah:

a. Return on Equity

Return on Equity (ROE) merupakan rasio yang berhubungan dengan laba yang dihasilkan atas modal sendiri. Menurut (Sudana, 2015) Return on Equity dirumuskan sebagai berikut:

\section{b. Earning Per Share}

$$
\text { Return On Equity }=\frac{\text { Earning after tax }}{\text { Total equity }}
$$

Earning Per Share (EPS) merupakan rasio laba atas setiap lembar saham. Menurut Fahmi (2014) Earning Per Share dirumuskan sebagai berikut:

$$
\text { Earning Per Share }=\frac{\text { Earning after tax }}{\text { Jumlah saham beredar }}
$$

Hasil

\section{Analisis Deskriptif}

Analisis deskriptif digunakan untuk memberikan gambaran mengenai data yang diteliti dilihat dari jumlah data, nilai maksimu, minimum, rata-rata, dan standar deviasi. Adapun hasil perhitungan statistik deskriptif menggunakan perangkat lunak IBM SPSS Statistik 24 adalah sebagai berikut:

Tabel 1. Hasil Uji Statistik Deskriptif

\begin{tabular}{lrrrrr}
\hline & $\mathrm{N}$ & \multicolumn{1}{c}{ Minimum } & \multicolumn{1}{c}{ Maximum } & \multicolumn{1}{c}{ Mean } & \multicolumn{1}{c}{ Std. Deviation } \\
\hline ROE & 32 & 1.39 & 29.65 & 11.7594 & 8.15909 \\
EPS & 32 & 92,07 & $1.589,91$ & 710,2391 & 440,16133 \\
NILAI_PERUSAHAAN & 32 & 1.37 & 5.96 & 3.3059 & 1.26911 \\
& & & & & \\
\hline Valid N (listwise) & 32 & & & &
\end{tabular}

\section{Koefesien Determinasi}

Koefesien determinasi untuk mengetahui besarnya kontribusi pengaruh variabel independen terhadap variabel dependen. Kurniawan dan Yuniarto (2016) menyatakan bahwa "Variabel y dapat dijelaskan oleh variabel $\mathrm{x}$ sebesar $\mathrm{r}^{2} \%$ dan sisanya dijelaskan oleh variabel lain". Berikut hasil pengujian koefesien determinasi menggunakan perangkat lunak IBM SPSS Statistik 24:

Tabel 2. Hasil Pengujian Koefesien Determinasi

Model Summary

\begin{tabular}{lrrrr} 
Model & $\mathrm{R}$ & R Square & Adjusted R Square & Std. Error of the Estimate \\
\hline 1 & $.802^{\mathrm{a}}$ & .643 & .619 & .78352 \\
\hline
\end{tabular}

a. Predictors: (Constant), EPS, ROE

Sumber: output SPSS 24 (data diolah) 


\section{Uji Regresi Linier Berganda}

Analisis regresi linear berganda digunakan untuk memprediksikan seberapa jauh perubahan nilai suatu variabel apabila nilai variabel lain dinaikturunkan (Kurniawan \& Yuniarto, 2016). Hasil uji regresi dengan menggunakan perangkat lunak IBM SPSS Statistik 24 adalah sebagai berikut:

Tabel 3. Uji Regresi Linier Berganda

\section{Coefficients $^{\mathrm{a}}$}

\begin{tabular}{|c|c|c|c|c|c|c|}
\hline \multirow[b]{2}{*}{ Mod } & & \multicolumn{2}{|c|}{ Unstandardized Coefficients } & $\begin{array}{l}\text { Standardized } \\
\text { Coefficients }\end{array}$ & \multirow[b]{2}{*}{$\mathrm{t}$} & \multirow[b]{2}{*}{ Sig. } \\
\hline & & B & Std. Error & Beta & & \\
\hline \multirow[t]{3}{*}{1} & (Constant) & 3.209 & .266 & & 12.048 & .000 \\
\hline & ROE & .311 & .043 & 2.002 & 7.182 & .000 \\
\hline & EPS & -.005 & .001 & -1.741 & -6.245 & .000 \\
\hline
\end{tabular}

a. Dependent Variable: NILAI_PERUSAHAAN

Sumber: output SPSS 24 (data diolah)

\section{Pengujian hipotesis secara simultan (Uji F)}

Uji $F$ digunakan untuk mengetahui hubungan variabel independen terhadap variabel dependen dalam mempengaruhi secara bersama-sama. Berikut hasil Uji $F$ yang diolah menggunakan perangkat lunak IBM SPSS Statistik 24:

Tabel 4. Hasil Uji F

\begin{tabular}{llrrrrr}
\multicolumn{7}{c}{ ANOVA $^{\text {a }}$} \\
\hline Model & & Sum of Squares & Df & Mean Square & F & \multicolumn{1}{c}{ Sig. } \\
\hline 1 & Regression & 32.127 & 2 & 16.063 & 26.166 & $.000^{b}$ \\
& Residual & 17.803 & 29 & .614 & & \\
& Total & 49.930 & 31 & & & \\
\hline
\end{tabular}

a. Dependent Variable: NILAI_PERUSAHAAN

b. Predictors: (Constant), EPS, ROE

Sumber: output SPSS 24 (data diolah)

\section{Pembahasan}

Pada tabel 1 hasil uji statistik deskriptif menggunakan perangkat lunak IBM SPSS statistik 24 dapat dilihat banyaknya data dalam penelitian yaitu 32 data yang bersumber dari laporan keuangan PT. Astra Agro Lestari Tbk. pada tahun 2010 sampai 2017 secara triwulan. ROE sebagai $X_{1}$ yang merupakan hasil dari laba bersih setelah pajak dengan total ekuitas memiliki nilai rata-rata sebesar 11,7594 dengan nilai standar deviasi sebesar 8,15909 yang lebih kecil dari nilai rata-rata. Juga diketahui nilai maksimum ROE adalah 29,65 dan nilai m inimum nya sebesar 1,39 .

Selanjutnya EPS sebagai $X_{2}$ yang merupakan hasil dari laba bersih setelah pajak dengan jumlah saham beredar memiliki nilai rata-rata 710,2391 dan nilai standar deviasi sebesar 440,16133 yang lebih kecil dari nilai rata-rata. Juga dapat diketahui nilai tertinggi EPS adalah 1.589,91 dan nilai terendah EPS adalah 92,07.

Nilai Perusahaan yang diindikasikan dengan PBV sebagai $Y$ yang merupakan hasil dari harga pasar saham dengan nilai buku memiliki nilai rata-rata sebesar 3,3059 dan standar deviasi sebesar 1,26911 yang lebih kecil dari nilai rata-rata. Juga diketahui nilai tertinggi PBV adalah 5,96 dan nilai terendahnya adalah 1,37.

Pada tabel 2 hasil koefesien determinasi menggunakan perangkat lunak IBM SPSS statistik 24 menunjukkan bahwa nilai $R$ square sebesar 0,643 atau $64,3 \%$ merupakan pengaruh variabel independen yaitu ROE dan EPS terhadap variabel dependen yaitu nilai perusahaan (PBV) dan sisanya sebesar $35,7 \%$ 
dipengaruhi oleh variabel-variabel lain yang tidak dimasukkan dalam penelitian ini. Nilai $R$ merupakan koefesien korelasi ganda dengan nilai 0,802 atau 8,02\% menunjukkan bahwa korelasi atau hubungan variabel independen yaitu Return on Equity dan Earning Per Share dengan variabel dependen yaitu nilai perusahaan adalah sangat kuat.

Pada tabel 3 hasil uji regresi linier berganda menggunakan perangkat lunak IBM SPSS statistik 24 terdapat persamaan regresi berganda antara variabel independen yaitu ROE dan EPS dan variabel dependen yaitu nilai perusahaan (PBV) adalah: $Y=3,209+0,311 X_{1}-0,005 X_{2}$

Maka berdasarkan hasil persamaan regresi berganda dapat dijelaskan sebagai berikut:

1. Nilai konstanta sebesar 3,209 artinya apabila semua variabel independen diasumsikan dalam keadaan nol maka nilai perusahaan akan sebesar 3,209.

2. Nilai koefesien ROE sebesar 0,311 artinya bahwa saat Return on Equity mengalami penambahan satu satuan maka variabel dependen yaitu nilai perusahaan akan mengalami peningkatan sebesar 0,311.

3. Nilai koefesien EPS sebesar -0,005 artinya bahwa saat Earning Per Share mengalami penambahan satu satuan maka variabel dependen yaitu nilai perusahaan akan mengalami penurunan sebesar 0,005.

Lalu berdasarkan tabel 4 hasil uji F menggunakan perangkat lunak IBM SPSS statistik 24 menunjukkan bahwa $F_{\text {hitung }}$ sebesar 26,166 lebih besar dari $F_{\text {tabel }}$ sebesar 3,33 yang didasarkan pada dk pembilang $=2$ dan $\mathrm{dk}$ penyebut $=(32-2-1)=29$ dengan taraf kesalahan sebesar $5 \%$ sehingga hasilnya $F_{\text {hitung }} \geq F_{\text {tabel }}=26,166 \geq 3,33$ berarti signifikan, ataupun dapat dilihat di tabel hasil uji $F$ dengan nilai signifikasi $0,000<0,05$ artinya memiliki hubungan yang signifikan.

Maka berdasarkan hasil penelitian, penelitian ini juga mendukung hasil peneltian terdahulu bahwa terdapat hubungan yang signifikan secara simultan antara variabel independen yaitu ROE dan EPS dan variabel dependen yaitu nilai perusahaan yang diindikasikan dengan PBV. ROE, EPS, dan nilai perusahaan juga menunjukkan hubungan yang sangat kuat dengan kontribusi variabel independen yaitu ROE dan EPS cukup besar untuk menetapkan variabel dependen yaitu nilai perusahaan (PBV). Maka melalui peningkatan nilai ROE dan EPS perusahaan dapat meningkatkan nilai perusahaan yang dikaitkan dengan nilai saham. Maka dapat menunjukkan pendapat Marlina (2013) dengan adanya peningkatan laba maka earning per share meningkat, dan dengan meningkatnya laba investor juga berharap return yang semakin besar hal ini diharapkan dapat meningkatkan price to book value.

\section{Kesimpulan dan Saran}

Berdasarkan hasil dari penelitian mengenai pengaruh Return on Equity dan Earning Per Share terhadap nilai perusahaan pada PT. Astra Agro Lestari Tbk. maka penulis dapat menarik kesimpulan bahwa hubungan antara Return on Equity dan Earning Per Share terhadap nilai perusahaan termasuk kategori sangat kuat. Return on Equity dan Earning Per Share secara bersama-sama berpengaruh negatif dan signifikan terhadap nilai perusahaan pada PT. Astra Agro Lestari Tbk.

Diharapkan penelitian selanjutnya dapat menambah sampel penelitian lebih banyak, perusahaan atau sektor perusahaan lainnya dan periode penelitian yang lebih lama agar bisa diambil keputusan yang lebih baik lagi juga diharapkan penelitian selanjutnya dapat menyempurnakan penelitian ini dengan menambahkan variabel independen lainnya baik itu berupa rasio keuangan atau faktor-faktor lain diluar rasio keuangan.

\section{Referensi}

Astuti, D. 2004. Manajemen Keuangan Perusahaan. Penerbit Ghalia Indonesia. Jakarta.

Azis, M. 2015. Manajemen Investasi Fundamental, Teknikal, Perilaku Investor dan Return Saham. Deepublish. Yogyakarta. https://books.google.co.id/books?isbn=6022806852 (Accessed Desember 9, 2018)

Christiana, I., \& Putri, L. P. (2017). Faktor-faktor yang Mempengaruh Price to Book Value. Jurnal Studi Akuntansi dan Keuangan, 1(1): 11-20. DOI: 10.5281/zenodo.1064186

Eti Rochaety, R. T. 2009. Metodologi Penelitian Bisnis: Dengan Aplikasi Spss (Revisi ed.). Mitra Wacana Media. Jakarta.

Fahmi, I. 2014. Manajemen Keuangan Perusahaan dan Pasar Modal. Mitra Wacana Media. Jakarta.

Gumanti, T. A. 2011. Manajemen Investasi. Mitra Wacana Media. Jakarta. 
Hery. 2017. Kajian Riset Akuntansi. PT Gramedia. Jakarta. https://books.google.co.id/books?isbn=6023759025 (Accessed Februari 3, 2019)

https://finance.yahoo.com/

Kasmir. 2013. Analisis Laporan Keuangan Rajawali Pers. Jakarta.

Kurniawan, R., \& Yuniarto, B. 2016. Analisis Regresi. Kencana. Jakarta. https://books.google.co.id/books?isbn=6024220340 (Accessed Desember 3, 2018)

Marangu, K., \& Jagongo, A. (2014). Price Book Value Ratio and Financial Statement Variables (An Empirical Study of Companies Quoted At Nairobi Securities Exchange, Kenya). Lobal Journal Of Commerce and Management Perpective, 3(6), 50-56.

Marlina, T. (2013). Pengaruh Earning Per Share, Return on Equity, Debt To Equity Ratio dan Size Terhadap Price To Book Value. Jurnal IImiah Akuntansi Kesatuan, 1(1), 59-71.

Puspitasari, D. 2015. Pengaruh Kinerja Keuangan Terhadap Nilai Perusahaan. 1-12. http://eprints.dinus.ac.id/id/eprint/17595 (Accessed Desember 13, 2018)

Rosyada, R. 2017. Pengaruh Leverage, Return On Equity (Roe), Dan Earning Per Share (Eps) Terhadap Nilai Perusahaan Pada Perusahaan Sektor Kelapa Sawit yang Terdaftar di ISSI (Indeks Saham Syariah Indonesia). http://eprints.radenfatah.ac.id/1058/ (Accessed Desember 14, 2018)

Sudana, I. M. 2015. Manajemen Keuangan Perusahaan (2nd ed.). Penerbit Erlangga. Jakarta.

Sugiyono. 2013. Metode Penelitian Bisnis (Vol. 17). Alfabeta CV. Bandung.

Suparno, \& Ramadini, R. (2017). Pengaruh Intellectual Capital dan Earning Per Sahre terhadao Nilai Perusahaan. Jurnal Manajemen dan Keuangan, 6(1), 710-716.

Suripto. 2015. Manajemen Keuangan: Strategi Penciptaan Nilai Perusahaan Melalui Pendekatan Economic Value. GRAHA ILMU. Yogyakarta.

Utari, D., Purwanti, A., and Prawironegoro, D. 2014. Manajemen Keuangan. Mitra Wacana Media. Jakarta.

www.astra-agro.co.id.

www.idx.co.id 